\title{
フィードラーの芸術論成立におけるゼムパーの被覆論の影響について ON THE INFLUENCE OF GOTTFRIED SEMPER'S THEORY OF DRESSING IN THE FORMATION OF KONRAD FIEDLER'S ART THEORY
}

\author{
河田智 成*
}

\section{Tomonari KAWATA}

\begin{abstract}
The purpose of this paper is to show the sequence from Gottfried Semper's theory of dressing to Konrad Fiedler's theory of pure visibility.

The following are the results of this study. Being guided by Semper, Fiedler grasped for the first time the idea of "purification of form by self-denial of material elements" as a whole which is core concept of the theory of pure visibility. Semper's theory of dressing had potentially the basis of Fiedler's theory understanding the artistic activity as intuitive cognition and the moment triggering visual activity treated in the theory of pure visibility.
\end{abstract}

Keywords : Gottfried Semper, Konrad Fiedler, Dressing, Symbol, Pure visibility, Modern age ゴットフリート・ゼムパー, コンラート・フィードラー, 被覆, 象徴, 純粋可視性, 近代

\section{1.はじめに}

コンラート・フィードラー (Konrad Fiedler, 1841-1895) は、純粋可視性 の理論によって近代芸術学の理論的地平を拓いたドイツの芸術学者 である。彼は、芸術の自律性確立を目指して、カント (Immanuel Kant, 1724-1804）による認識批判の枠組みを芸術活動の領域へと拡張し、芸 術活動の本質を美の創造にではなく直観的認識に求めて、芸術活動 の内的構造を明らかにしようと試みた1。フィードラーの主著と目さ れるのは、最初の刊行物である『造形芸術作品の評価について』 (1876) [FS1:1-48] (以下、『評価』と表記) と、集大成とも言える『芸術 活動の根源について』(1887) [FS1:111-220]（以下、『根源』と表記）であ る2。フィードラーが、この 2 つの主著のあいだ、『評価』の直後に、 ゴットフリート・ゼムパー (Gottfried Semper, 1803-1879) の『技術的・構築 的諸芸術における様式』(1860-1863)（以下、『様式』と表記）に触発され て著したのが、建築論「建築芸術の本質と歴史に関する覚書」(1878) [FS2:291-323] (以下、「覚書」と表記) である3。本稿では、ゼムパーと フィードラーのあいだのこうした影響関係に注目して、フィード ラーの芸術論成立においてゼムパーが果たした役割を探る4。

フィードラーの純粋可視性の理論については、それが、近代抽象 絵画へと向かう芸術的反省を促したことから、また、ヒルデブラン ト (Adolf von Hildebrand, 1847-1921) を介して、リーグル (Alois Riegl, 1858-
1905)、ヴェルフリン (Heinrich Wölfflin, 1864-1945)、シュマルゾー (August Schmarsow, 1853-1936) らの芸術の基礎概念探究を導いたことから、美術 史学の主要テーマのひとつとして、すでに多く論じられている5。そ の形成過程についても、カントの認識批判をはじめ、フンボルト (Karl Wilhelm von Humboldt, 1767-1835) の言語哲学など、さまざまな影響 が指摘されている6。ゼムパーからフィードラーへの影響に関して は、フィードラー研究においては、フィードラーがゼムパーの建築 論に拠りながら「覚書」を著したという事実の紹介にとどまるのが 一般的である7。そんななかで、フィードラーの芸術論全体における ゼムパーの影響の内実にまで踏み込んで、両者の影響関係を論じて いるのが、マルグレイブによるゼムパー研究である。マルグレイブ は、ゼムパーの影響の広範性の一例として、フィードラーの建築論 「覚書」に触れ、それがゼムパー理論への一種の解説となっているこ とを指摘している。そして、ゼムパーからフィードラーへの影響を、 1.フィードラーがゼムパーの被覆論を「形式の脱物質化」として哲 学的な方向で引き継いだこと、2．ゼムパーがローマ建築に認めた空 間芸術の可能性を、ロマネスク建築のヴォールトを架けて空間を隔 離するという理念に見出して具体的に展開したことに見ている8。本 稿は、マルグレイブが示したゼムパーからフィードラーへの影響 1 に関わるものである9 。 
本稿では、まず第 1 章で、フィードラーの建築論「覚書」と 2 つの 主著『評価』『根源』とを比較しながら、これらの著作における芸術 活動の捉え方の展開に着目して、ゼムパーからの影響がフィード ラーの芸術論成立においていかなる契機となったのかを探る。それ によって、マルグレイブが示した影響 1 を具体的に確認できるだろ う。つづく第 2 章では、ゼムパーの被覆論がいかにフィードラーの 純粋可視性の理論へと繋がったのかを具体的に示すために、被覆の 象徵作用を巡るゼムパーの言説のなかに、フィードラーの純粋可視 性の理論へと通じる理路を探る。こうした考察を通して、フィード ラーの芸術論成立におけるゼムパーの影響を具体的に明らかにした w。

\section{2.フィードラーの芸術論成立におけるゼムパーの影響}

\section{2-1.「覚書」における芸術的建築活動の捉え方}

「覚書」は、芸術的建築活動の本質を捉え、その歴史を概観しよう というもので、序にあたる部分と 3 つの章を持つ本論から成る。 フィードラーは、序に打いて、建築芸術を何か外在的なものによっ て理解しようとする美術史研究の現状を批判し、建築芸術の起源に 遡ってその成立を見とどけようとするゼムパーの試みに、こうした 状況を打開する綡口を見出す。続く第 1 章でギリシャ建築を、第 2 章 でローマ建築やゴシック建築を、第 3 章でロマネスク建築を取り上 げ、それぞれの芸術的価值について検討を加えている。フィード ラーは、オーダーを用いた建築芸術としてはギリシャ建築を、アー チとヴオールトとを用いた建築芸術としてはロマネスク建築を高く 評価する一方で、ローマ建築以後の古典主義建築については、芸術 的創造とは無縁の借り物、ゴシック建築についても、芸術的には無 価值な技術的産物と見做す 10 。こうした評価を支えているのが、 フィードラーの芸術的建築活動に対する捉え方である。

フィードラーは、第 1 章第 1 段落・第 2 段落という「覚書」本論の 冒頭で、彼がいかに芸術的建築活動を捉えているのかを示して、論 を開始している。「覚書」全体の論を支える重要性を持つ部分であ る。

まず第 1 章第 1 段落を引用しておく。「ゼムパーは、古代の建築作 品にける、原始の建築的形式の変容を跡付けている。原始の建築的 形式は、基本的な生活必需品と利用可能な建築素材の本性とに由来 する諸条件から直接生まれたものであるが、ゼムパーが示すのは、 それらの形式が、その起源から離れるに従って、いかに種々様々に 形態化されて行くのか、それらの形式が、それ自身を現すところの 素材を繰り返し変えながら、いかに無意識的に変化しているのか、 それらの形式に、それを生じた地、それを用いた民族の特性が、い かに刻印されているのか、ということだ。ゼムパーは、ギリシャ文 化最盛期の建築作品を古代建築最高の精華と見做す。より厳密に言 えば、古代ギリシャの地で原始の形式要素が芸術的に成熟した原因 を、それまで構築と建築素材とに由来する諸条件に左右されて、そ の痕跡を抱えていた形式から、こうした依存の足枷を解こうという 努力に見るのである。この努力の結果、「芸術作品は、直観において、 手段と素材とを忘れさせ、それによって、その姿を現し、作用する とともに、形式として自足する」11ことになる。」FS2:298]

第 1 段落前半で、ゼムパーの歴史的方法が要約され、後半で、ゼ ムパー理論の創意がゼムパーを引用しながら簡潔に示されている ${ }^{12} 。$
フィードラーは、ゼムパーの建築論を、このように捉えた上で、「覚 書」の序において、「建築芸術の本質に対する理解が全く未熟」

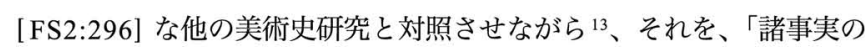
真の関係を捉える統一的な見通しをもって、諸々の芸術形式の成立・ 変容・消滅を辿り」[FS2:297]、「芸術としての本性と意味とを何より芸 術作品のなかに見極めようとする特異な試み」 [FS2:297] と評価してい たのである。ゼムパーは、当時誤解されたように、芸術外的な物質 的諸条件が芸術形式を直接規定するという、唯物的芸術論を展開し たわけではなかった。フィードラーによれば、ゼムパーは、「芸術形 式として自らを表現する、精神特有の働きを熟知する者」[FS2:297] と して、一見唯物的とも取れる歴史的方法の上に、「芸術としての本性 と意味とを何より芸術作品のなかに見極めようとする」独自の理論 を展開したのである。フィードラーは、当時見逃されていたゼム パー理論の創意を理解し、それに触発されたと言える ${ }^{14}$ 。

続く第 2 段落において、フィードラーは、前段落でのゼムパー理 論の要約を受けて、それを、建築美学批判を織り交ぜながら、芸術 活動を直観的認識として捉える彼の芸術論の核心へと繋げて行く。 その後、第 2 段落終わり近くで、芸術的建築活動について次のよう に述べる。「建築作品が形式の純粋な表現となってはじめて、作品と して形態化するという精神的営為は全うされる。こうしてょうやく、 建築作品は、最高の意味での人間精神の産物・所有物となり、芸術 作品として、人間精神最高のエッセンスに相応しいと主張できるの である。」[FS2:300] 芸術表現をともなう直観的認識によって、建築作品 を精神的産物へと、すなわち、形式の純粋な表現へと高めること、こ れがフィードラーの考える芸術的建築活動である。

さらに、こうした芸術的建築活動に対する主張を、ゼムパー理論 を手掛かりにギリシャ建築論を展開した後、第 1 章の終わり近くで も、次のように 2 度言い換えて提示している。「我々は、美的にどう 感じるかには囚われないで、ギリシャ建築の形式における、精神の 生き生きとした活動を認識するように努めなければならない。そこ では、精神は、未熟な段階から最高の段階へと上昇して行く以外に、 つまり、物質的諸力が優位に立って形式を拘束しているような段階 から、それらの物質的因子が残らず形式の単なる表現手段と化すこ とで、形式が何よりもまず自立した精神的所産として現れる、その ような段階へと進んで行く以外に、芸術的な充足を得ることができ なかったのだ。」[FS2:305-306]「盛期ギリシャの建築作品を理解すること について話題にするには、次のようなことを意識しておく必要があ る。つまり、いかにして、純粋な形式表現を獲得しようとする力が、 建築作品のあらゆる部分を掌握して行ったのか。いかにして、曇り のない明晰な芸術的意識が、巨大な量塊にも、些細な細部にも浸透 して行ったのか。また、いかにして、あらゆる線、比例、形式のひ とつひとつが、その美的な質の故にではなく、ゆるぎない確信を もって、構築上の制約を想起させるものすべてを消し去るように、 適切に選ばれたのか。そしてついには、いかにして、材料自体、そ れがどんなに貴重であろうと、スタッコと塗料とで覆われて、自ら を主張せず、より高度なものを表現するために㗢くようになったの か。こうしたことを意識しながら、ギリシャの建築作品を考察する なら、そこで、人間が、ひとつの領域における最高の成果へと至つ たのだということを、認めるに違いない。その建築作品を直観する とき、そこには形式以外の何ものも現れず、あらゆる物質的要素が 
完全に精神化され、建築作品自体が物質的存在から離脱しているか のようである。」[FS2:306 ${ }^{15}$

まず 1 度目の言い換えでは、「建築作品が形式の純粋な表現とな」 ることを、形式が自立した精神的所産として現れることであると言 い換え、そのことが、物質的因子が形式の表現手段と化すことに よって、すなわち、物質的要素の自己否定によって実現すると説い ている。次の 2 度目の言い換えでは、芸術的建築活動によって産出 される作品の特性を述べるなかで、物質的要素の自己否定を物質的 要素の精神化として捉え直している。また、それに先立って、芸術 表現をともなう直観的認識の実相をギリシャ建築に即して示してい るが、これは同時に、物質的要素の自己否定による形式の純粋化の ひとつの具体的なあり方として捉え得るだろう。

以上より、「覚書」において、フィードラーは、芸術的建築活動を 直観的認識とした上で、その本質を、ゼムパーに導かれて、「物質的 要素の自己否定による形式の純粋化」として捉えていたと言える。

\section{2 - 2. 『評価』『根源』における芸術活動の捉え方との比較}

フィードラーは、『根源』で、「人間が視覚像をより高度な存在へ と発展させ得るのは、もつぱらひとつの活動のおかげなのであり、 その活動によって、可視的に明白な造形物が産出されるのである。 そして、この活動こそ芸術活動に他ならない」[FS1:145] と述べ、芸術 活動をまずは可視的に明白な造形物を産出することであるとする。 そして、こうした造形物をいかに実現するかと言えば、造形の素材 に触机て、「素材は、視覚に現れる物自体の形態のような、非物質的 形象を表現するという目的のためだけに利用される。そういう意味 で、それはいわば自己否定を強いられている」[FS1:192] と論じている ことから、素材の自己否定を通してであることが分かる。この言説 につづけて、フィードラーはさらに、「物質的要素の自己否定」のあ り方に触れながら、「可視的に明白な造形物」を次のように捉え直し ている。「自然を芸術的表象とするために、自然の側でなされなけれ ばならない変化は、素材を使った活動によってのみ達成され得る。 また、素材から芸術作品を作り出すために、素材の側に起こらなけ ればならないことは、自然を介してのみ達成され得る。自然の表現 に素材を従わせるのである。そして、この両者が、芸術活動におけ るしかるべき努力によって制御された、形式化の働きのもとに置か れることによってはじめて、芸術の世界が成立し得る。この芸術の 世界において、事物の可視性は、純粋な形式の造形物という形態を とつて実現されるのである。」[FS1:192-193]つまり、「可視的に明白な造 形物」とは、「形式の純粋な造形物」に他ならない。『根源』でも芸 術活動を、「覚書」においてと同様に、「物質的要素の自己否定によ る形式の純粋化」として捉えていることは明らかである。

『評価』では、芸術活動を直観的認識として把握し、それを、能動 的構成によって精神的に獲得すること、換言すれば、可視的現象か ら精神に対して存在可能な形式を創造することと捉えた上で [FS1:3132]、この直観的認識による芸術的努力の最高の段階を、「あらゆる 形式、あらゆる形態を、その完全な存在にまで造り上げること」 [FS1:37] に見ている。さらに、そうした段階を、「直観があらゆる部分 において明晰な精神の表象となり、完全な必然的存在となる」[FS1:38] 状態として捉え、つづけて次のように述べる。「これこそ、芸術家が 創造的認識を推し進め得る最高の段階である。完全な明晰性と必然 性とは一致する。 [FS1:38] これらの言説から、『評価』では芸術活動
を、形式を完全な明晰性と必然性を備えた存在とすることとして捉 えていることが分かる。明晰性・必然性・完全性といつた鍵語は、「覚 書」『根源』にも頻出するものの ${ }^{16}$ 、「覚書」において「形式の純粋化」 として捉え直されるものであろう。

『評価』では、上述のように、芸術活動を「形式の純粋化」として 捉える趣旨の言説が繰り返されていた。次に、これと表裹をなすと 見做し得る、「物質的要素の自己否定」に繋がる言説を確認して行 $<$ 。

フィードラーは、『評価』において、技術について次のように述べ ている。「芸術的精神が自らの内にあるものを最高の存在にまで高め ようと欲するのであれば、芸術作品を制作するための技術的な巧み さも必要になる。技術は芸術活動において自立した権利を持ってい ない。それはただ精神的過程に仕えるだけである。精神が支配権を 行使できない場合にのみ、技術は、自立した意味や重要性を得て発 達するが、芸術的には無価値となる。芸術家における精神的営みは、 芸術作品において可視的現象となるところの素材以外のものとは、 はじめから無関係である。芸術作品とは形態化という活動の外的結 果であり、芸術作品の内容とは形態化すること自体に他ならない。」 [FS1:36-37] フィードラーは、ここで、いわば技術の自己否定について 説いており、「物質的要素の自己否定」を論じた「覚書」の言説に接 近している。しかし、「覚書」以後、物質的要素の主対象とも言える 素材の手段化、自己否定が強調されるのに対して、技術の自己否定 に主題が限定されており、「物質的要素の自己否定」が全体として主 題化されているとは言い難い。

『評価』での次の言説は、「物質的要素の自己否定」に直接言及す るものではないが、それを示唆するであろう。「芸術家は、多くの発 展段階において現象を彼にとって意味深いものとしてきたあらゆる ものを、その途上で振り捨てる。現象自体が芸術家の認識力に服す ればするほど、現象の属性は彼に対する影響力を失うのである。」 [FS1:37] これが、直観的認識によって形式を完全な存在にまで高める ことを説いた直後のものであることを考慮すれば、「その途上」と は、「あらゆる形式、あらゆる形態を、その完全な存在にまで造り上 げる」途上を意味する。ならば、これは、直観的認識の過程におい て、形式の明晰性と必然性とが追求されることを、裹面から、「物質 的要素の自己否定」を示唆するかたちで言ったものと捉え得る。

結局、『評価』では、芸術活動を「形式の純粋化」を意味する概念 によって捉えていたものの、「物質的要素の自己否定」については、 主題を限定するかたちで論じられ、全体としては「形式の純粋化」の 裏面として示唆されるに止まっている。いずれにしても、「覚書」や 『根源』でのように、「物質的要素の自己否定」のあり方にまで踏み 込んで、それを主題化するには至っていないと言える ${ }^{17} 。$

それでも、「覚書」には、「我々は、視ること自体によって視られ たものを了解しようと試みることによって、はじめて、我々の可視 的世界像がいかなる状態にあるのかを洞察し得るのである」 [FS1:154] といつた、『根源』に見られる純粋可視性への徹底は認められない。 何より、そこには、『根源』で主題のひとつとなる、純粋可視性の表 現に不可欠な、「眼と手の協働」に対する考察がない [FS1:157-168] ${ }^{18}$ 。 フィードラーは、「覚書」では未だ、可視的現象を可視的造形物へと もたらすなかで達成される純粋可視性を、それ自体として理論的に 展開・深化するには至っていない。 
以上、フィードラーが純粋可視性の理論を大きく展開したのは、 晚年の主著『根源』においてであったが、彼は、その理論の中核と 成る「物質的要素の自己否定による形式の純粋化」という概念を、ゼ ムパーに導かれながら、「覚書」ではじめて全体として主題化したこ とを確認した。次章では、ゼムパーの被覆論のなかに、それがフィー ドラーの純粋可視性の理論へと慗がって行く理路を探ってみたい。

3. ゼムパーの被覆論からフィードラーの純粋可視性の理論へ 3-1. ゼムパーの被覆論における被覆の象徵作用

ゼムパーの被覆論は、被覆における構造とその表現との関係を論 じるもので、ゼムパーは、その重要性を次のように述べている。「古 代ギリシャ芸術が受け継いだ形式的要素のなかで、被覆の原則、外 殼の原則ほど根本的に重要なものはない。それは、古代ギリシャ以 前のあらゆる芸術を制御しており、ギリシャ様式においても、決し てその重要性を低下させたり減少させたりすることなく、高度に精 神化され、構造技術的 (struktiv-technish) な意味においてより、構造象徴 的 (struktiv-symbolisch) な意味において、もつぱら美と形式のために生き 続けている。」SS1:220]こうした観点に立って、ゼムパーは『様式』に おいて、ギリシャに先行するアッシリアとエジプトにおける被覆の あり方を論じた後 [SS1:337-392, 405-426]、ギリシャにおける被覆のあ り方を論じている [SS1:438-479]。彼は、これらを、その建築体におけ る表層とコアとの関係に応じて、3 つにモデル化して捉える。すなわ ち、表層が外款化・構造化し、コアが中空化したアッシリア (アジア) モデル [SS1:443] 、表層が装飾化し、コアが構造化したエジプトモデル [SS1:443] 、表層が構造象徴化し、コアが構造化したギリシャモデルで ある19。ギリシャモデルを特徵付けている構造象徵という概念が、被 覆論における重要概念であり、ここで問題とする被覆の象徵作用も、 この構造象徴の働きに他ならない。

ギリシャモデルについて、ゼムパーは次のように述べる。「ギリ シャ神殿は、エジプトの原則に従ったが、ただより洗練された方法 である完全な切石整層積によって建てられ、より高度な構造象徵的 な意味で解釈された、アジアの外殼の原則に従って仕上げられた。 こうした組み合わせによって、被覆は、その物質的役割から自由に なり、ただ形式的思考 (formaler Gedanke) を伝達するものとして現れる と同時に、石の継ざ目、一般に建築素材を隱して、形式的思考を建 築素材からいわば解放するのである。こうして、形式は、それ自身 と、そこに込められた有機的理念だけで、説明できるものになる。」 [SS1:443-444] さらに、次のようにも述べている。「ギリシャのような原 則は、明らかに、物質的な工作物を覆い隠すことを好む、形式上の 伝統に立脚していなければならなかった。こうした伝統なしに、何 か純粋な思弁から、ギリシャの原則が成立するなどということは、 決してあり得ない。その伝統こそアジアのものだった。( 改行) そこで の問題はもっぱら、アジア的被覆としての構造が有する必要に基づ く機械的な形式を、動的で有機的な形式へと変容させ、そこに魂を 吹き込むことであった。また、形態学的目的を欠いたもの、純粋な 形式的理念に馴染まず、そ机に反しているもの、こうしたものを残 らず排除するか、中立的な領域へと追放することであった。新しい 創造の本質は、所与のものを吟味し、それを精神化することにあっ たのであり、新しい型の創作にはなかった。」SS1:444]

要約すれば、ギリシャモデルは、覆い隠すことを好むアジア的伝
統に立脚して、技術的に洗練されたエジプトモデルに従って建てら れ、構造象徴的に再解釈されたアッシリアモデルに従って仕上げら れるものである。その時、被覆は、構造象徵として、形式的思考を 伝達するものとなり、それによって形式は、形式自身と有機的理念 だけによって説明可能な、精神化されたものとなる、とされる。こ こでまず、被覆の象徴作用を、形式的思考の伝達による形式の精神 化と捉え得るだろう。

ゼムパーの被覆論は、彼が「色彩被覆」とも呼んでいたポリクロ ミーへの関心に端を発して形成されたものである。ゼムパーは上述 のようにギリシャモデルを論じるなかで、ポリクロミーを次のよう に捉えている。「こうした潮流のなかで、古代ギリシャの建築原理 は、最も巧妙で非物体的な被覆として、とりわけ色彩について、そ の効果を立証し、磨いて行く必要があった。色彩は、物質を被覆す るものでありながら、それ自身は非物質的であるから、現実を捨て 去る完全な手段である。 [SS1:445] 20これと次の言説をあわせて見れば、 「現実を捨て去る完全な手段」とされるポリクロミーの効果を、ゼム パーがぞのように捉えていたかを知ることができる。「形式が、意味 深い象徵として、人間の自立した創造物として現れるべきところで は、現実の破棄、物質的なものの破棄が不可欠だ。( 中略) 高度に芸術 を発展させた時代の巨匠たちは、現実を覆い隠すマスクからも物質 的なものを覆い隠したのである。」 [SS1:231] すなわち、ポリクロミーの 効果とは、物質的現実を破棄して、形式を意味深い象徵として現す ことである。

こうしたポリクロミーの効果は、ギリシャモデルにおける被覆の 象徵作用、また、このモデルを特徵付けている構造象徵の働きと見 做し得る。この効果における、形式を意味深い象徴として現すとい うことは、構造象徴が「もつぱら美と形式のために」あるという上 述のゼムパーの言説に照らせば、形式を、他の何かを象徵するもの としてではなく、形式自体を象徴する「形式的象徴」として、芸術 的に現すことであると分かる。したがって、ここでは、被覆の象徴 作用を、物質的現実の破棄による形式的象徴の芸術的顕現と捉え得 るだろう ${ }^{21}$ 。

被覆論の重要概念となっている構造象徵という概念にもう少し説 明を加えておこう。被覆論は、ゼムパー初期のポリクロミーへの関 心が、彼が建築の四要素 (炉、囲い、屋根、基壇)のひとつとした、「囲 い」を論じるなかに包摂されて形成されたものであった ${ }^{22}$ 。ゼムパー は、古代アッシリアの外殼化した板状壁面に、織物によって空間を 隔離するという「囲い」の理念の象徴を認めて、素材が変わつても 被覆に「囲い」の理念が継承されて行くことを見出した。このよう な経緯から、彼は、被覆を、もともとの素材での形式の成り立ちを 想起させる象徴と捉えて、構造象徴にも、こうした構造表現的意味 を与えて用いることがある。しかし、ゼムパーは、これを足掛かり に被覆論をさらに展開し、被覆を、個々の要素の元素材や成り立ち を想起させる象徴としてだけでなく、物質的現実を破棄して、形式 を全体として形式自体の象徴と化し芸術的に現すものとして捉えて いる。ここで問題としている構造象徵とは、この意味におけるもの である。

これで、ゼムパーの被覆論における構造象徴としての被覆の作用 を、1．被覆が形式的思考を伝達することで、形式を精神化すること、 2. 被覆が物質的現実を破棄することで、形式的象徵を芸術的に顕現 
させること、以上の 2 点として、それぞれ「形式的思考」「形式的象 徵」を鍵概念とするかたちで整理できた。

\section{3-2．被覆の象徵作用からフィードラーの純粋可視性の理論へ}

前節に示した被覆の象徴作用 $1 \cdot 2$ は、フィードラーの純粋可視性の 理論の中核概念「物質的要素の自己否定による形式の純粋化」およ び、これを導いたゼムパーの言説「芸術作品は、直観において、手 段と素材とを忘れさせ、それによって、その姿を現し、作用すると ともに、形式として自足する」 [SS1:232] を含意していよう。純粋可視 性の理論の中核概念で言えば、「物質的要素の自己否定」が、被覆の 象徴作用 2 の「被覆が物質的現実を破棄すること」を意味すること は明らかであるとして、「形式の純粋化」についても、被覆の象徴作 用 1 の「形式を精神化すること」、被覆の象徵作用 2 の「形式的象徵 を芸術的に顕現させること」と重なるものである。被覆の象徴作用 1 における精神化された形式とは、「それ(形式) 自身と、そこに込め られた有機的理念だけで、説明できるもの」だったし、「形態学的目 的を欠いたもの、純粋な形式的理念に馴染まず、それに反している もの、こうしたものを残らず排除」したものだった。また、被覆の 象徵作用 2 における形式的象徵とは、形式による形式自体の象徵で あった。これらはみな、「形式の純粋な表現」を意味していると見做 し得よう。そして、フィードラーも、2-1 節で言及したように、「建 築作品が形式の純粋な表現とな」ることを、形式が自立した精神的 所産として現れることだと言い換えていた。ここにも、「形式の純粋 化」と被覆の象徵作用 1 の「形式を精神化すること」との意味の重 なりを認めることができる。このように、被覆の象徴作用 $1 \cdot 2$ と純粋 可視性の理論の中核概念とは一体とも言える関係にある。フィード ラーは、ゼムパーが繰り返し提示した被覆の象徴作用から、純粋可 視性の理論の中核概念を取り出したのである。

ゼムパーの被覆論とフィードラーの純粋可視性の理論のあいだの 繋がり自体は確認できた。では、両理論がいかに繋がり得たのか、以 下、その契機を被覆の象徴作用 $1 \cdot 2$ のなかに探ろう。

まず、被覆の象徵作用 1 、特に、その形式的思考という概念に注目 してみる。フィードラーは、「覚書」で、形式的思考に関連して、次 のように述べている。「建築芸術における芸術的な形態化の過程とい うものは、必要に応じた諸要求と技術的熟練とから生じたものに対 して、別に規定されたある必要条件に適った形式を、まるで外側か ら押し付けるというょうな、歴然としたものではないのだ。我々は むしろ、建築芸術の形態化の過程を、思考の仕方 (eine Art des Denkens) として表象してみなければならない。この思考の内容を成すものは、 建築的形式そのものであり、この思考の深化を特徴付けているのは、 形式の変容にともなって、素材と構築とが次第に消滅するなかで、 精神に属する形式がますます自立的な存在へと展開して行くという ことである。建築的に思考することは、単に発明したり組み合わせ たりすることでも、所与の諸法則に従って形式化したり形態化した りすることでもない。それは、ただひとつの法則を内在した過程で ある。なぜなら、この過程が、そもそも思考することであろうとす るなら、その本質は、所与の材料から純粋な精神の所産を創り上げ ようと模索することでなければならないからだ。」[FS2:301]

被覆の象徴作用 1 にある形式的思考に対して、ゼムパーは明瞭な 説明を与えていないが、こうした言説から、フィードラーが、形式 的思考の深化を、芸術的な建築的形式の生成過程、換言すれば、「物
質的要素の自己否定による形式の純粋化」として捉えていることが 分かる。ここからも、被覆の象徵作用 1 と純粋可視性の理論の中核 概念との慗がりがはっきりと読み取れる。

2-2 節に示したように、フィードラーは『評価』において、芸術活 動を直観的認識と見做し、その本質を、形式を完全な明晰性と必然 性を備えた存在とすること、すなわち、「形式の純粋化」に見ていた。 そこで既に、認識過程と形式生成過程とを重ねて捉えていたのであ る ${ }^{23}$ 。フィードラーは、被覆の象徵作用 1 の形式的思考という概念に、 思考過程と形式生成過程とのパラレルな結び付きを読み込み、芸術 活動を直観的認識として捉える自らの考え方に重㸚たと見ることも 可能だろう。そうだとすれば、形式的思考という概念が、ゼムパー の被覆論とフィードラーの純粋可視性の理論とを繋ぐ蝶番として働 き、「形式の純粋化」の裏面として示唆されるに止まっていた「物質 的要素の自己否定」を「覚書」で前景化する契機となったと見做し 得る。何れにしても、ゼムパーの被覆論に、「形式的思考」というか たちで、フィードラーの純粋可視性の理論の大前提である、芸術活 動を直観的認識として捉える考え方が、孕まれていたのである。

次に、被覆の象徵作用 $2 、$ 特に、その形式的象徵という概念に注目 して、フィードラー理論のさらなる展開へと繋がる契機を示してお きたい。被覆の象徵作用 2 では、ポリクロミーによる被覆の効果と して、「形式が、意味深い象徵として、人間の自立した創造物として 現れる」、つまり、形式的象徵の芸術的顕現が言われていた。この象 徵が、上述のように、形式による形式自体の象徵であることを考え れば、被覆の象徴作用には、形式を視覚によって観る、より正確に は、物質的現実ではなく、形式的象徵の芸術的顕現を視覚によって 観ようとする眼の衝きが伏在するであろう。ならば、被覆の象徴作 用 1 によって伝達される形式的思考も、フィードラーが形式的「思 考の内容を成すものは、建築的形式そのもの」と論じているように、 あくまで形式として伝達されるだろうから、そこにも同じように、 形式を視覚によって観る眼の働きを想定できよう。

結局、形式を巡る概念を鍵とする被覆の象徵作用に、フィード ラーの純粋可視性の理論に不可欠な「眼の観る働き」を誘発する契 機が孕まれていたと捉え得る。だとすれば、ゼムパーが、被覆論を 論じて、被覆の象徵作用を繰り返し示したのに対して、フィード ラーは、この被覆の象徵作用のなかに「眼の観る働き」を捉えて関 心を集中し、そこから「眼と手の協働」による表現する働きへと進 んで、純粋可視性の理論を展開したと考え得よう。

以上、被覆の象徴作用のなかに、フィードラーの純粋可視性に通 じる理路を見出してきた。被覆の象徵作用によって伝達される「形 式的思考」には、芸術活動を直観的認識として捉えるフィードラー 理論の前提への萌芽が、被覆の象徴作用による「形式的象徴の芸術 的䫓現」には、純粋可視性の理論で問われる「眼の観る働き」を誘 発する契機が、それぞれろまれていたのである。

\section{4. おわりに}

ゼムパーの『様式』とフィードラーの「覚書」を主な分析対象と して、フィードラーの芸術論成立においてゼムパーがいかなる役割 を果たしたのかを探ってきた。考察の結果、フィードラーが、ゼム パーに導かれてはじめて、それまで「形式の純粋化」の裏面として 触孔るに過ぎなかった「物質的要素の自己否定」をその内実から捉 
え、両面をあわせて純粋可視性の理論の中核概念として確立したこ とを確認した。そして、ゼムパーの被覆論に、フィードラーの純粋 可視性の理論の前提である、芸術活動を直観的認識として捉える考 え方の芽を、また、純粋可視性の理論で問われる「眼の観る働き」を 誘発する契機を見出し、ゼムパーの被覆論からフィードラーの純粋 可視性の理論への理路として示した。

フィードラーは、『評価』で、建築においては芸術活動と非芸術活 動とを区別することが容易ではなく、絵画史や彫刻史に比べて、建 築芸術史を構想することにはより大きな困難がともなうと述べてい た[FS1:12] 24。「覚書」では、その題目が示すように、あえてこの困難 な課題に取り組んで、芸術的建築活動の本質を建築芸術史を踏まえ ながら追究したものと考元得る。そして、そこで、ゼムパーの建築 論に拠りながら、建築という物質的制約の大きい芸術を対象に、直 観的認識としての芸術活動のあり方を具体的に考察したことが、か えって、「形式の純粋化」の裏面として示唆されるに過ぎなかった 「物質的要素の自己否定」を、その内実から捉える機会となり、 フィードラーに純粋可視性の理論への展開を促したと言える。 フィードラーの芸術論成立における「覚書」の重要性はここにある。 また、そこでゼムパーが果たした役割は小さいものではないだろう。 ゼムパーの建築論を継承したとされるヴァーグナー (Otto Wagner, 1841-1918) は、ゼムパー理論の唯物的側面に近代性を認め、綱領的な 近代建築論へと発展させる一方で、ゼムパーの構造象徴の概念には 前近代性を見出した ${ }^{25}$ 。フィードラーによるゼムパー理論の受容とは 対照的に見える。では、ゼムパーとフィードラーとの繋がりに、い かなる近代建築史的な意味が見出させるのか、最後に、この点に触 れておきたい。

ゼムパーの被覆論の影響の下に形成されたフィードラーの純粋可 視性の理論は、芸術に打ける造形表現の近代化に大きな役割を果た した。このことから、ゼムパーとフィードラーとの繋がりが持つ近 代建築史的な意味も見えてくるだろう。1 7 世紀末にペロー (Claude Perrault, 1613-1688) は、オーダーの比例を絶対視することに疑問を呈し て、それを慣習による美とした ${ }^{26}$ これに端を発するのが、様式に基 づく建築表現を克服して、純粋に視覚的な構成に基づく建築表現を 追求するという、建築表現近代化の潮流である。ヴァーグナーもま た、その作品によって、この流れを決定的に推し進めた建築家のひ とりであった。こうした建築表現の近代化が、純粋可視性の理論の 影響下に進んだ芸術における造形表現の近代化と連動して、近代建 築の美学の重要な一面を成したことを考劣れば、ゼムパーとフィー ドラーとの繋がりも、建築表現の近代化を支えた理論的底流のひと つと見做すことができるだろう 27 これも、ゼムパーの建築論が近代 建築に与えた広範な影響の一端なのである。

\section{注}

本文および注における下記文献への参照は、次の文献略記号と頁数によっ て示した。

SS1 : Gottfried Semper, Der Stil in den technischen und tektonischen Künsten, oder praktische Ästhetik. ein Handbuch für Techniker, Künstler und Kunstfreunde, Bd.1, Verlag für Kunst und Wissenschaft, Frankfurt a. M., 1860.

FS1 : Konrad Fiedler, Schriften zur Kunst I, Hrsg. von Gottfried Boehm, Wilhelm Fink Verlag, München, 2. Aufl. 1991.

FS2 : Konrad Fiedler, Schriften zur Kunst II, Hrsg. von Gottfried Boehm, Wilhelm Fink Verlag, München, 2. Aufl. 1991.
1) フィードラーは、芸術活動の本質を、美の創造ではなく、芸術的形成によ る直観的認識におき、それを、概念による科学的認識と同様に精神的に所有 することであると主張する [FS1:27,30-32,168-170,178-180]。こうした芸術活動 の捉元方は、フィードラーがカントの『純粋理性批判』(A:1781/B:1787) から 学んだものである。それはつまり、人間に世界が与えられているのではな く、人間が知覚や表象によって世界を構築しており、この構築こそが世界を 精神的に所有すること、認識することに他ならない、という人間の認識活動 に対する考え方であり、フィードラーは、これを芸術理解に援用して芸術模 倣説の克服を計り、近代の芸術論にコペルニクス的転回をもたらした。

2) Konrad Fiedler, Über die Beurteilung von Werken der bildenden Kunst, S.Hirzel, Leipzig, 1876. Konrad Fiedler, Über den Ursprung der künstlerischen Tätigkeit, S.Hirzel, Leipzig, 1887. 『評価』には、金田廉訳「美術品の評価に就いて」(『フィードレル芸術 論」金田廉訳、青磁社、1947 年、9-81 頁所収) が、『根源』には、山崎正和・ 物部晃二訳「芸術活動の根源」(『世界の名著 81 近代の芸術論』山崎正和編、 中央公論社、1979 年、57-169 頁所収) が邦訳としてあり、適宜参考にした。

3) Konrad Fiedler, "Bemerkungen über Wesen und Geschichte der Baukunst" in Deutsche Rundschau XV, 1878, S.361-83. 建築をテーマとするフィードラーの論文は、刊 行されたものとしては、この「覚書」が唯一のものである。他の建築に触れ る言説は、遺稿中の断章 $62,64,75$ などのように [FS2:40-41,45]、ほとんどが断 片的なものにとどまる。「覚書」の直後に同じ誌上に発表された " Über Kunstinteressen und deren Förderung" in Deutsche Rundschau XXI, 1879, S.49-70 のなか に、袋小路に入り込んでいた同時代の建築活動に対する比較的まとまった批 判的言説があるが[FS1:54-58]、そこにおける芸術的建築活動の捉方方自体は 「覚書」のそれを踏襲している。未刊行のものとしては、『評価』刊行以前に 行った講演を含む、建築をテーマとする草稿が 4 編、Fiedleriana II, 16, a-d とし て遺されている[FS1:XXVI-XXVII,XLII]。これらは、それぞれ、エルサレムの 神殿建築、スペインの中世建築、ロマネスク建築、パレルモのノルマン建築 を対象としており、フィードラー著作集の編者ゴットフリート・ベームも言 うように、個別限定的な美術史的テーマを扱ったものである [FS1:XXIV]。こ れらの草稿において、フィードラーの芸術論成立に深く関わるギリシャ建築 論のような論が展開されているとは考学難い。しかし、ここから、フィード ラーの建築芸術に対する関心が『評価』刊行以前の初期からのものであり、 建築芸術に対する多彩なテーマを講じ得る深い造詣の上に「覚書」が成立し ていることを覾い得るだろう。

4) フィードラーは、『評価』に、建築史研究が抱える問題を次のように記して いる。「対象を歴史的に論じながら、その本質を成す芸術的側面にはほとん ど注意を払わない、そのような美術史が可能になる。絵画や彫刻の歴史が、 こうした危険に陥ることは比較的少ないものの、建築芸術を歷史的に論じる 場合には、しばしばこの主張が証明される。建築作品においては、他の芸術 作品よりも、いずれの部分が芸術活動に基づいており、いずれの部分が芸術 的要求や能力とは異なるものに負っているのかを、区別することが難しい。 だから、建築史は、個々の建築作品に芸術的実質を見出したり、広い建築活 動の領域のなかに人間の芸術的能力が現れている形式を歴史的に追跡すると いった、困難な課題を引き受けずに、しばしば安易な道を選んでしまってい る。建てることと建築芸術とを区別しないから、建築形式の歴史を提供して おきながら、それらの形式が持つ芸術的質の歷史については触れることがな いのだ。」[FS1:12]『評価』で芸術活動に対する考察をまとめたフィードラー は、この第一の主著刊行後、建築芸術史を構想することの困難性に対するこ うした認識の下、「覚書」で芸術的建築活動の本質を建築芸術史を踏まえな がら追究したものと考光得る。とは言え、前注に記したように、フィードラ 一は既に『評価』以前に個別の建築を論じたこともあり、「覚書」における 芸術的建築活動に対する見方が、『評価』後に形成されたとは断定できない。 しかし、『評価』での芸術活動に対する見方には認められず、「覚書」での芸 術的建築活動に対する見方と『根源』での芸術活動に対する見方に共通して 認められる論点があるならば、少なくとも、そうした論点については、『評 価』では芸術活動に対する見方と未だ結び付いておらず、『評価』後に芸術 活動に対する見方と結び付いて、『根源』での考察へと展開したと捉え得る だろう。こうした観点から、フィードラーの芸術論成立における建築論「覚 書」の位置を確認してみたい。

5) フィードラーは、『評価』『根源』の何れにおいても、また、建築論「覚書」 でも同様に、芸術活動の本質を人間精神の本性に遡って問うことの必要性 を、論を始めるなかで説いている[FS1:2,112, FS2:296]。彼は、美術史研究が 実証的・文化史的史料編纂へと傾くなかで、芸術作品をそれ自体として理解 するために、芸術活動の本質へと目を向けるよう促したのである。こうした 彼の問題提起を起点に、リーグルやヴェルフリンが、芸術外的なものによつ て芸術を理解することを拒否し、芸術の自律性を論証するために、その自律 
性を根拠付ける基礎概念の探究へと乗り出す。しかし、彼らは、フィードラ 一の純粋可視性の理論の一側面であった視覚概念に重きを置いて、視覚形式 の様式という観点から造形芸術の自律性を論証しょうとしたため、結局、あ らゆる造形芸術を図式的な視覚形式へと還元してしまう。そこでは、フィー ドラーの『根源』での主張、「それ(身体の営みと精神の営み) は常に同一の 事象なのである。人間の本性に扔いて身体的でないような精神の営みはあり 得ないから、身体的なのであり、我々にとって精神的な形式をとらないよう な身体の営みはあり得ないから、精神的なのである」[FS1:136] といった心身 一元論の主張が、等䦥視された。フィードラーのこうした主張を継承したの が、シュマルゾーであった。シュマルゾーは、リーグルやヴェルフリンの視 覚偏向を批判し、芸術をその成立の根源から捉え直そうというフィードラー の問いかけに回帰した。彼は、「眼と手の協㗢」を不可欠としたフィードラ 一の純粋可視性の理論を心身一元論に発するものと捉えて、芸術活動の基礎 に身体を置き、身体の構造が、人閒が世界を把握する形式であって、芸術活 動を規定するものと見たのである。芸術内的・外的以前の身体内在的な基礎 概念の探究へと進んだシュマルゾーの試みは、メルロー＝ポンテイ (Maurice Merleau-Ponty, 1908-1961) の現象学的身体論を予告するものであつた。フィー ドラーの繰り返した問題提起は、このように、近代の芸術学・美術史の多様 な展開の起点となったのである。フィードラーの芸術論を取り巻く諸問題に ついては、神林恒道·太田喬夫・上倉庸敬編『芸術学の軌跡』、勁草書房、1992 年にコンパクトに䌂められている。特に、フィードラーと近代絵画との関係 については、その第I部第 3 章「芸術学を支えるもの - 藝術の自立性一」を、 フィードラーを起点とする芸術の基礎概念探究については、第 II 部第 1 章 「基礎概念の時代」を参照。

6) ゴットフリート・ベーム編集フィードラー著作集のベームによる序文 [FS1:XLV-XCVII]、および、その第2 版に寄せた彼の付記が [FS1:VII-XXII]、優 れたフィードラー論となっており、カント、フンボルトからの影響を中心 に、カッシーラー (Ernst Cassirer, 1874-1945) のシンボル哲学への影響、フッサ ール (Edmund Husserl, 1859-1938) の現象学との親近性など、さまざまな影響関 係が指摘されている。また、そこに整理された文献目録もあわせて見れば [FS1:XXXII-XL]、フィードラーに関する既往研究を概観することができる。 ただ、ベームは、この序文・付記において、ゼムパーとフィードラーとの関 係については触れていない。ベームのフィードラー論としては、ゴットフリ ート・ベーム「眼の論理 - コンラート・フィードラー没後百年 -」井面信行 訳、『理想』656、1995 年 12 月、50-60 頁も参照。

7) フィードラー研究の側から見れば、「覚書」は、それが主著と見做されてい ないため、取り上げられないことも多い。しかし、美術批評家のヴェントゥ ーリなどは、「覚書」を、原則として理論的反省にとどまったフィードラー が美術史を具体的に展開しょうとした貴重な記録として評価し、その内容を 吟味している。それでも、ゼムパーからの影響を事実として指摘するだけ で、影響の内実を主題化してはいない。リオネッロ・ヴェントゥーリ『美術 批評史』辻茂訳、みすず書房、第二版 1971 年、274-275 頁を参照。日本では、 吉岡健二郎が『近代芸術学の成立と課題』創文社、1975 年、34-37頁に「覚 書」を比較的詳しく取り上げて、芸術と美とを同一視しないフィードラーの ギリシャ建築に対する見方を紹介している。そして、それがゼムパーの様式 論に触発されたものであることを指摘しているものの、その影響の内実には 触れていない。

8) Harry Francis Mallgrave \& Eleftherios Ikonomou trans., Empathy, Form, and Space : Problems in German Aesthetics 1873-1893, The Getty Center for the History of Art and the Humanities, Santa Monica, 1994, pp.31-35. Harry Francis Mallgrave, Gottfried Semper : Architect of the Nineteenth Century, Yale University Press, New Haven \& London, 1996, pp.289,368. Gottfried Semper, Style in the Technical and Tectonic Arts ; or, Practical Aesthetics, tr.by Harry Francis Mallgrave \& Michael Robinson, The Getty Research Institute, Los Angeles, 2004, pp.49,54. 9) 次稿ではゼムパーとフィードラーによる建築様式評価を取り上げる。マル グレイブが示したゼムパーからフィードラーへの影響 2 については、次稿で 改めて論じたい。

10) 前注参照。

11) 本稿では、Form の訳語に「形式」をあてた。ドイツ語にはこれに近い概念 としてGestalt があるが、それには「形態」をあてた。高取万里子、川向正 人「G．ゼムパーの陶芸論における Formについて」『日本建築学会 2011 年度 大会学術講演梗概集 (建築歴史・意匠) 」、727-728 頁には、ゼムパーがこうし た概念を使い分けていたという指摘がなされている。なお、Gebildeには「造 形物」ないしは「形象」をあてている。

12) フィードラーによる引用は [SS1:232]、ゼムパーが空間隔離の理念の成立を 論じるなかで注記したものの一部である [SS1:227-232]。

13）フィードラーは、「党書」の序において、当時の美術史研究の状況を、「外
面的で、皮相的で、副次的にしか見えないものだけが、歷史的に論究され」 [FS2:296-297]、「ある芸術作品に関するあらゆることを説明しておきながら、 何よりその作品を芸術作品たらしめているもの、それに関してだけは何も明 らかにしない」[FS2:297] と、撖しく批判している。

14）ゼムパーは、目的や素材、技術の限定の上に成立する建築や工芸が、そう した制約を超えて純粋形式へと至るときに、芸術的表現を獲得すると考えて おり、決して、芸術外的な物質的諸条件が芸術形式を直接規定するといった 単純な唯物論者ではなかった。しかし、彼の理論は、追随者にさえ䛊解さ れ、単純化され、唯物的芸術論の代表格と捉えられて行く。こうした唯物的 芸術論は、やがて、「芸術意志」に芸術形式の展開動因を見るリーグルによ って厳しく批判されるようになる。リーグルは、目的や素材、技術を芸術形 式の生成・展開における摩擦係数と見立てて、唯物的芸術論に対する批判を 展開したのであるが、ゼムパー自身は、上述のように、芸術外的な物質的諸 条件が芸術形式を直接規定するとは考えない上に、こうした制約を、純粋形 式に向けた精神化の過程に必須の所与と見做し、いわば芸術形式へのスプリ ングボードと捉えており、唯物的芸術論とも「芸術意志」とも異なる地点に 立っていたと言える。フィードラーによるゼムパー理解は、こうした唯物主 義者ゼムパーという誤解のなかで、ゼムパー理論の全体像を捉えた先駆的な 例と言える。ゼムパー理論の広範な影響に関しては、Mallgrave, op.cit., pp.355381 を参照。

15ここには、ゼムパーの被覆論からの直接的な影響が見て取れる。

16) 必然性 (Notwendigkeit) という語に関しては、『評洒』以後、次第に鍵語とし て扱われなくなり、『根源』では、様々に言い換えられている。例兄ば、「芸 術活動はSachlichkeit と明晰性に基づ」[FS1:172]くとか、芸術の純粋「世界に おいては、事物の現象は、理解ある芸術家の眼に、明確性、秩序、 Gesetzmäßigkeit を帯びて現れ」[FS1:201] るなどと述べられる。ここには必然 性と同趣旨の語への言い換えが認められるだろう。さらに、『根源』の最終 段落では、「その絶対的価值は、そこで人間の意識がその発展能力の最高の 段階に達しているという点にある」[FS1:220] とされるが、この「絶対的」に ついても、同様の意味合いを持つであろう。

17）『釷価』における芸術活動に対する理解が発展途上にあるというフィードラ 一の意識を、「世界の芸術的理解の本質がどこにあるのか、ここではまだ示 すことができない」[FS1:17] という彼の言説に読み取ることも可能であろう。 18）フィードラーは『根源』の第 4 章をこのテーマにあてて考察し、後の現象 学的身体論にも関係付け得る次のような主張を展開している。「手は、眼自 身が活動を終えるにいたったまさにその地点で、眼の行うことを引き継い で、さらにそれを発展させるのである。」FS1:165]「いわゆる精神活動の発展 は、それをいっさいの身体活動から分離してしまえば、およそ成り立ち得な いのであって、むしろそれは、つねに同時に身体活動の発展でなければなら ないのである。」[FS1:167]

19）アッシリアモデルについては、「既に発達した後期カルデア・アッシリア建 築において、被覆は、構造的でかつ装飾的な原則によっている。建物で唯一 固定されたものは、その外殼である。被覆することと外殼を施すこととが結 び付いた、純粋に技術的な処置は、(中略) 建築的な芸術シェマと、さらに は装飾まで生み出した。この装飾は、同時に、ただ付随的にではあるが、象 徵となる、ないしは象徴となり得る。被覆は、ここでは、純粋に技術的・現 実的な仕方で形式を与えるものとして、現れるのである。ここに、言葉の持 つ真に物質的な意味に抢ける、中空体構造が成立する」 [SS1:443] とされる。 エジプトモデルについては、「そ机に対して、エジプト建築は、理念に従っ て被覆を何らかの方法で構造と関係付けるというようなことをしょうとはし なかった。事実上、構造が被覆を吸収している、つまり、構造が石の量塊と なり、被覆はそこに彫り込まれているのである。それでも、被覆を、実際に は一体である構造から、その意図に従って分離しているように見せることに よって、反構造的とも言える、被覆の個有性は保たれている」[SS1:443] とさ れる。

20) ゼムパーは、ポリクロミーのあり方に関係付けて、ギリシャモデルの完成 度を捉えている。すなわち、ギリシャ建築は、大理石以外の材料をスタッコ で被覆し彩色したものから [SS1:450-451]、大理石に直接彩色を施したものと なる。そして、この彩色に蛕画が導入されることで被覆の脱物質化が完遂さ れ[SS1:467-468]、ギリシャモデルの完成を見るのである。こうした被覆の効 果については、次注を参照。さらに、彩色されたパネルによる被覆が登場す ると、アジア的被覆への退行がはじまるとされる [SS1:471]。

21)ゼムパーは、Die vier Elemente der Baukunst : Ein Beitrag zur vergleichenden Baukunde, Vieweg und Sohn, Braunschweig, 1851 において、建築の四要素(炉、囲い、屋根、 基壇)のひとつとしての「囲い」の議論とポリクロミーへの関心とを結び付 けて、はじめて被覆論を説いた。Ibid., S.39-40で、彼は、ギリシャ全盛期に 
は白大理石建築の全面にポリクロミーが施されていたことを主張し、次のよ うに述へている。「大理石神殿は、白色や淡黄色ではなく、飽和状態の色彩 に溢れ、輝いていたのだ。それが与える主な印象は、おおよそ、今なおそれ を際立たせている色調の通りであったが、ただより輝き、しかもより軽やか であった。なぜなら、その下で石の白と結晶が透けて微かに輝く、赤みがか ったガラス状の被覆のためであり、これと交互に現れる、わずかに緑がか り、黒によって和らげられた青い色彩のためであり、全体を細い網目で包 み、主要部分を輝かせる薄い塗金のためである。このような色調は、あらゆ る古代のテラコッタに根強く見られるのに、どうして神殿ではあり得なかっ たとしなければならいのだろうか。(改行) それで、建物の量塊は、南の地方 で真昼に空の低い部分が輝く、その輝きのなかに溶け込んでいくのであり、 今日の画家たちは、この軽やかな輝きに、鉛丹を用いて近づくことができる だけである。」既にここで、『様式』での言説を先取りして、ポリクロミーに よる建築量塊の脱物質化を言っている。

22) 前注参照。ポリクロミー論争から被覆論へと至るゼムパーの建築論の形成 については、川向正人の一連の論文に詳しい。「G. ゼムパーの「被覆論」の 形成過程について:ドイッ・オーストリアを中心とする 19 世紀歴史主義の研 究 (その2)」日本建築学会計画系論文報告集第 379 号、1987 年 9 月、138-147 頁、「ゴットフリート・ゼムパーのポリクロミー観に関する研究」同第 530 号、 2000 年 4 月、235-242 頁、「ゴットフリート・ゼムパーの始原への探究に関す る研究」同第 537 号、2000年 11 月、275-282 頁、「ゴットフリート・ゼムパー の『建築の四要素』に関する研究」同第 538 号、2000 年 12 月、235-242 頁、 「ゴットフリート・ゼムパーの『科学・産業・芸術』に関する研究」同第 583 号、 2004 年 9 月、165-172 頁を参照。

23)『評価』での「芸術活動に終わりはない。それは、絶え間なく続けられる精 神の作業であり、現象の世界を自らの意識のなかにますます豊かに展開し、
ますます完全に形態化しょうという作業である」FS1:35] という言説などか らも、フィードラーが直観的認識の過程と芸術的な形態化の過程とをひとつ のものとして見ていることが分かる。

24) 注 4 参照。建築における芸術活動と非芸術活動との区別の困難性について は、「覚書」において、フィードラーがゴシック建築を技術主導として厳し く評㑛する際に、具体的かつ徽底的に言及される [FS2:313-316]。フィードラ 一のゴシック建築評価については、ゼムパーとフィードラーによる建築様式 評価を論じる次稿で取り上げる。

25) ヴァーグナーのゼムパー評価をよく表しているのが、次の言説である。「こ の(「芸術を支配するものは必要のみ」という) 真理にわれわれの注意を向け

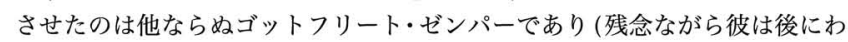
き道に逸れたが)、このことだけで、彼は、すでにかなり明らかにわれわれ に進むべき道を示していた。「しかし、彼はダーウィンのように自分の理論 を徹底的に一貫させる勇気をもたず、構造そのものを建築芸術の原細胞と見 ないで、それを象徴的に扱うことで済ませていた。 Otto Wagner, Die Baukunst unserer Zeit, Löcker Verlag, Wien, 1979 (Nachdruck der IV. Aufl., Verlag Schroll, Wien, 1914), S.58-59, S.61. 訳は、オットー・ヴァーグナー『近代建築』桶口清、佐久間博 訳、中央公論美術出版、1985 年、54 頁、56 頁による。

26) Claude Perrault, Les dix livres d'architecture de Vitruve corrigez et traduits nouvellement en François, avec des Notes et des Figures, Paris, 1673 で、それまで自律的建築言語 と見做されていたオーダーの根拠が疑われた。Wolfgang Herrmann, The Theory of Claude Perrault, A. Zwemmer, London, 1973 を参照。

27) フィードラーの純粋可視性の理論を心身一元論に発するものと捉えて、身 体に基づく空間論へと展開させたシュマルゾーまで視野に入れて、ゼムパー とフィードラーとの慗がりを見るなら、そこに、建築表現の近代化に止まら ない意味を見出すことも不可能ではないだろう。注 5 参照。 